\title{
Central American woolly opossum (Caluromys derbianus): distribution, ecology and conservation threats in Panamá
} \section{Zarigüeya lanuda centroamericana (Caluromys derbianus): distribución, ecología y amenazas para su conservación en Panamá}

\author{
Josué Ortega ${ }^{1,2 *}$, Carolina Mitre-Ramos ${ }^{3}$, Inga Geipel ${ }^{2}$, Marcos Ponce ${ }^{4}$, Publio González ${ }^{5}$, José de Jesús Vargas-González ${ }^{6,7}$, and Sergio Bermúdez ${ }^{8,9}$ \\ 'Fundación Yaguará Panamá, Clayton, Edificio 181, C. P. 0833-0292. Ciudad del Saber, Panamá. E-mail: josueortega26@yahoo.es (JO). \\ ${ }^{2}$ Smithsonian Tropical Research Institute, Balboa, Ancon, C. P. 0843-03092. Ciudad de Panamá, Panamá. E-mail: \\ inga.geipel@gmail.com (IG). \\ ${ }^{3}$ Universidad de Panamá, Escuela de Biología, Vella Vista, Edificio 7, C. P. 0824-00021. Ciudad de Panamá, Panamá. E-mail: \\ carolina.mitre@up.ac.pa (CM-R). \\ ${ }^{4}$ Museo Herpetológico de Chiriquí, C. P. 0426-01459. Ciudad de David, Panamá. E-mail: marcosponce27@gmail.com (MP). \\ ${ }^{5}$ Departamento de Investigación en Enfermedades Emergentes y Zoonóticas, Instituto Conmemorativo Gorgas, C. P. $0816-02593$. \\ Ciudad de Panamá, Panamá. E-mail: publiogd@gmail.com (PG). \\ ${ }^{6}$ The Peregrine Fund, 5668 West Flying Hawk Lane, Boise, C. P. 83709. Idaho, U. S. A. E-mail: jvargas.gonz@gmail.com (JJV-G). \\ ${ }^{7}$ Fundación Rapaces y Bosques de Panamá. La Chorrera, C. P. 1015-00326. Panamá Oeste, Panamá. \\ ${ }^{8}$ Departamento de Investigación en Entomología Médica, Instituto Conmemorativo Gorgas, C. P. 0816-02593. Ciudad de Panamá, \\ Panamá. E-mail: sbermudez@gorgas.gob.pa (SB). \\ ${ }^{9}$ Estación Científica Coiba, Coiba AIP, Clayton. Ciudad del Saber, Panamá. \\ *Corresponding author
}

\begin{abstract}
Little is known about the distribution and ecology of the Central American woolly opossum (Caluromys derbianus) in Panamá. Therefore, the aim of this study is to update geographical data and ecological information to fill this gap. Based on examinations of museum specimens, published data and field observations, we obtained 362 records of $C$. derbianus in Panamá. Our results suggest a wide distribution of $C$. derbianus across both natural and disturbed lowland environments. Moreover, we provide baseline information about its potential anthropogenic and natural threats, as well as general aspects of its diet in Panamá.
\end{abstract}

Key words: Central America; depredation; Didelphidae; diet; environments; synanthropic; threats.

Existe poco conocimiento de la distribución y ecología de la zarigüeya lanuda centroamericana (Caluromys derbianus) en Panamá. Por lo tanto, el objetivo de este trabajo es actualizar datos geográficos e información ecológica para llenar este vacío. Con base en revisiones de especímenes de museos, datos publicados y observaciones de campo, obtuvimos 362 registros de C. derbianus en Panamá. Nuestros resultados muestran una amplia distribución de C. derbianus entre ambientes de tierras bajas tanto naturales como perturbados. Adicionalmente, proporcionamos información base de sus amenazas potenciales naturales y antrópicas, así como aspectos generales sobre su dieta en Panamá.

Palabras clave: Ambientes; amenazas; América Central; depredación; Didelphidae; dieta; sinantropía.

๑) 2021 Asociación Mexicana de Mastozoología, www.mastozoologiamexicana.org

American marsupials include the orders Microbiotheria (1 species) and Didelphimorphia (18 genera and 110 species), which are primarily known as opossums (Voss and Jansa 2009; Amador and Giannini 2016). The most commonly found opossums belong to the genus Didelphis due to their synanthropic behavior; however, other species may go unnoticed or be known only by sporadic findings (Reid 2009). This is the case of the Central American woolly opossum Caluromys derbianus (Waterhouse 1841), a species with a distribution that extends from southern México to Ecuador, occupying regions ranging from sea level to 2,600 m (Bucher and Hoffmann 1980; Fonseca and Astúa 2015). Through its wide distribution, very little is known about their biology. Some studies have looked at its distribution (Fonseca and Astúa 2015; Marineros et al. 2016), ecological importance in the predation of insects, small vertebrates, seed disperser and as a pollinating agent (Lessa and da Cota 2010; Kays et al. 2012). In addition, it plays an important role as a prey for other species (Moreno et al. 2006; Marineros et al. 2016).

In Panamá, the diversity of opossums includes 10 species in 8 genera. Of these, $C$. derbianus has 4 subspecies: C.d.derbianus, C.d. nauticus, C. d. centralis, and C. d. pallidus (Bucher and Hoffmann 1980). Apart from sporadic anecdotes, only few studies provide information on the geographic distribution, ecology and conservation threats of this species. Therefore, the aim of this work is to update the known distribution of $C$. derbianus in Panamá by providing a comprehensive set of historical and current records, and to expand on the basic ecological and conservation threats. 
For the historical data, we reviewed specimens of $C$. derbianus deposited in the "Dr. Eustorgio Méndez" Zoological Collection of the Gorgas Commemorative Gorgas Institute for Health Studies (CoZEM-ICGES), in Panamá. Besides, we systematically reviewed the literature on this species using databases (BioOne, Smithsonian Libraries, and PubMed), including digital databases of the Smithsonian National Museum of Natural History (USNM), Washington, D. C., U. S. A.; American Museum of Natural History (AMNH), New York, U. S. A.; Philip L Wright Zoological Museum (UMZM), Montana, U. S. A., and the Museum of Vertebrate Zoology (MVZ), California, U. S. A.

Further, we collected recent data from personal observations, animals captured in scientific field studies, photos from camera traps, and revision of dead individuals (which were road-killed, electrocuted, preyed or hunted). We also used confirmed records from iNaturalist Panamá (an online citizen science platform, https://Panamá.inaturalist.org/). For each occurrence point, we recorded data on vegetation cover, type of environment and number of individuals. Finally, we used these historical (1884-1999) and current (2000-2020) data for C. derbianus in Panamá to create a map using ArcGis 10.3 software (Esri, Redlands, California, U. S. A.).

We obtained a total of 362 records of $C$. derbianus in Panamá, of which 174 are historical records (1884-1999) and 188 are current records (2000-2020; Figure 1). We obtained photographs of $C$. $d$. centralis (Figure $2 \mathrm{~A}$ ) and of an individual that showed a pale gray coloration (Figure 2B), which corresponds to an adult of the subspecies $C$. $d$. pallidus (Bucher and Hoffmann 1980; Fonseca and Astúa 2015).
The broad distribution of the records across Panamá indicate that the species occurs in different types of environments and at elevations that range from sea level to more than 2,000 $\mathrm{m}$. The distribution range included urban and rural sites, primary forest (e. g., Darien National Park), in addition to the islands of the Gulf of Montijo and Chiriqui (Pacific Ocean), the archipelago of Bocas del Toro, and the island of Escudo de Veraguas (Caribbean Sea; Figure 1). Rural areas corresponded to $31.4 \%$ of the data, followed by primary forests (30.3\%), secondary forests $(15.9 \%)$, gallery forests $(8.0 \%)$, suburban areas $(8.0 \%)$ and urban areas (6.4\%; Figure 1).

Of the 188 current records from photos and direct field observations, $11.2 \%$ provided information on the diet of C. derbianus ( $n=21$; Figures 2C, 2D), including bananas (Musa sp.; $1.6 \%$ ), oranges (Citrus sp.; $1.1 \%$ ), guavas (Psidium guajava; $0.5 \%$ ), figs (Ficus sp.; $0.5 \%$ ), guabas (Inga sp.; $0.5 \%$ ), jobos (Spondias mombin; $0.5 \%$ ), mangos (Mangifera indica; $0.5 \%$ ), cashew fruits (Anacardium occidentale; $0.5 \%$ ), pink poma (Syzygium jambos; $0.5 \%$ ), Malay rose apple (Syzygium malaccense; $0.5 \%)$, palm seeds $(0.5$ $\%)$ and other fruits $(0.5 \%)$. We also found evidence of consumption of nectar in raft flowers (Ochroma pyramidale; $1.6 \%$ ), poultry eggs (1.1\%), and insects (Orthoptera, Tettigoniidae; $0.5 \%$ ).

Current records came mainly from direct sightings (75.5\%), road-kills (6.9\%), captures for scientific purposes (5.3\%), electrocuted individuals (4.8\%), wildlife rescues $(2.1 \%)$, camera traps detections $(1.6 \%)$, predation by dogs $(1.6 \%)$, predation by spectacled owl (Pulsatrix perspicillata; $1.1 \%)$, predation by domestic cats $(0.5 \%)$, and individu-

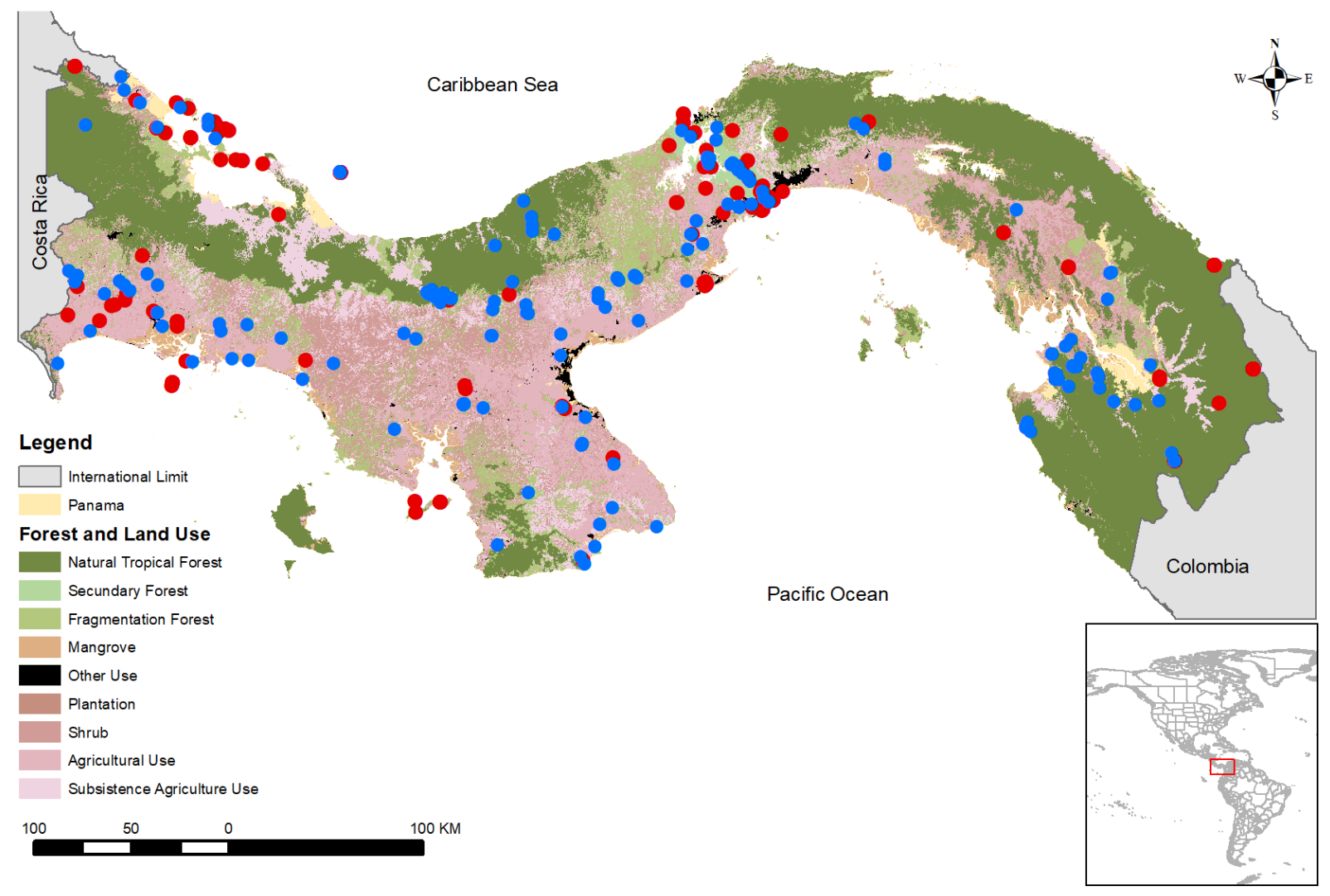

Figure 1. Historical occurrence (red dots, 1884-1999) and current occurrence (blue dots, 2000-2020) of Caluromys derbianus in Panamá. 


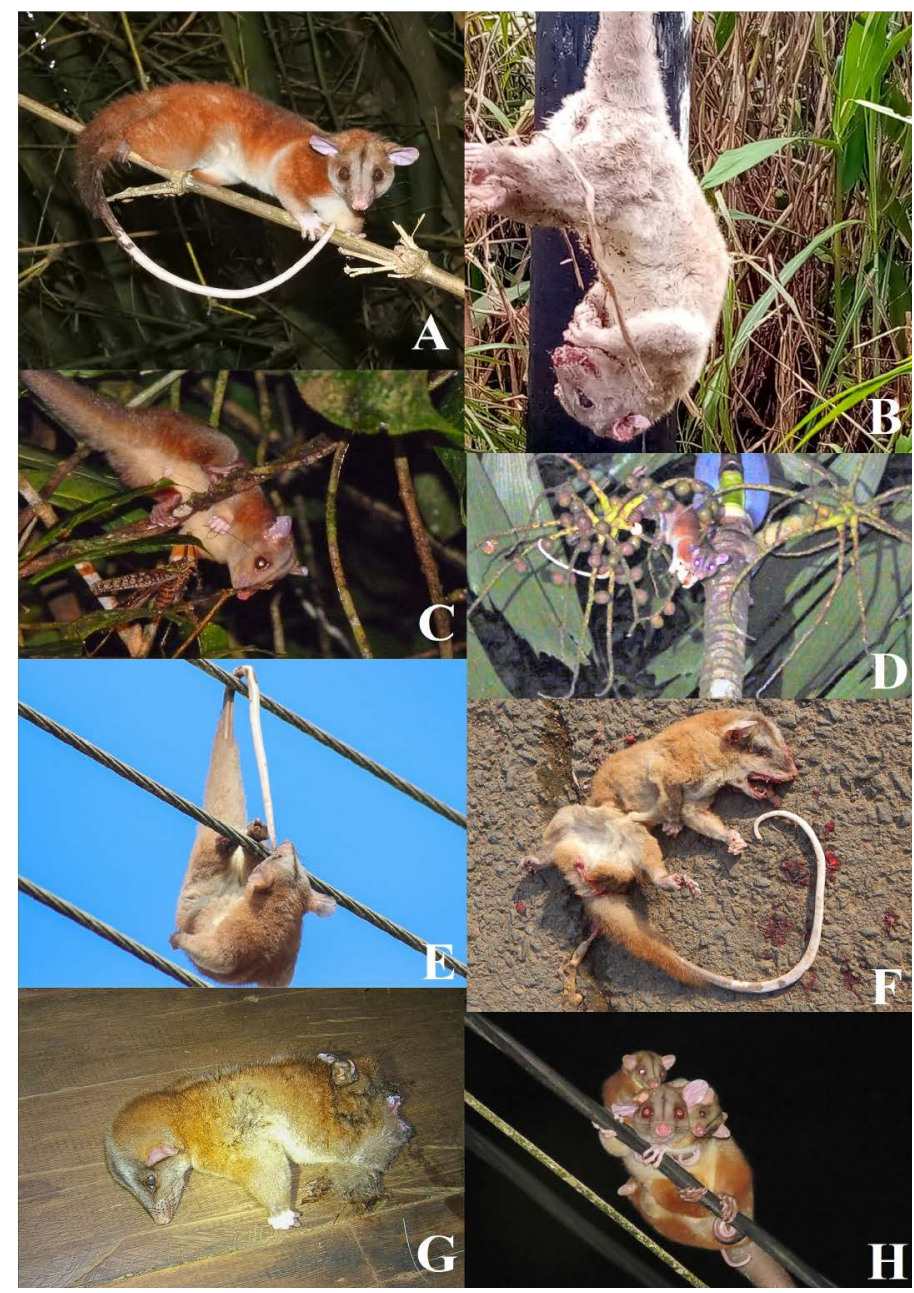

Figure 2. Morphology and subspecies of Caluromys derbianus in Panamá: $C . d$. centralis in Changuinola, Bocas del Toro province (A); C. d. pallidus, in Breñon, Chiriqui province (B). Diet evidenced in photographs: eating Orthoptera Tettigonidae, Donoso, Colon, province $(C)$; eating palm seeds in Darien National Park (D). Threats and risks: electrocuted, Parita, Herrera province (E); road-killed in La Colorada, Veraguas province (F); killed by domestic cat, Panama province (G). Maternal care in El Valle de Anton, Cocle province (H). Photograph by M. Ponce (A) and (C), M. de Landis (B), J. Ortega (D) and (F), O. Rodríguez (E), S. Roles (G), M. Urriola (H).

als hunted by humans $(0.5 \%)$. We present photographic evidence of electrocuted individuals, road-kills, and predation by domestic cats in Figures 2E-2G. Some photographic records show events such as 4 young on the body of their mother (Figure $2 \mathrm{H}$ ).

In addition, we describe two predation events of a spectacled owl (P. perspicillata) on a Central American woolly opossum in Panamá. The first incident occurred on Barro Colorado Island, where a spectacled owl attacked a male Central American woolly opossum that managed to escape into a water drainage culvert. Pictures from a camera trap which was set up in the drainage to monitor a bat roost, showed that the opossum was heavily injured on the head and the forelimbs (Figures 3A-3D). The second event occurred when as a Central American woolly opossum was searching for $S$. malaccense fruits. A spectacled owl landed on the opossum and grabbed it. The opossum began to scream and fight. The owl took off with the opossum in its claws, while the opossum was still alive, screaming and fighting. The owl landed on a distant tree, where the screaming stopped shortly after.
Caluromys derbianus shows a high adaptability to survive and thrive in a variety of ecosystems, which can explain its wide distribution in the Neotropics (Bucher and Hoffmann 1980; Fonseca and Astúa 2015; Marineros et al. 2016). The data obtained here confirmed the capacity of adaptation of this species in Panamá, which includes continental areas and islands such as Paridas, Brava, Cebaco and Gobernadora (Pacific coast), the archipelago of Bocas del Toro, and the island Escudo de Veraguas (Caribbean coast; Handley 1966; Bucher and Hoffmann 1980; Fonseca and Astúa 2015). The presence of $C$. derbianus on Coiba island, offshore Panamá (Pacific Ocean), remains to be confirmed (Juste and GuillénServent 1997), and based on Bucher and Hoffman (1980) it may correspond with the subspecies $C$. d. nauticus.

Compared to scansorial species like Didelphis marsupialis, the preference for inhabiting the canopy allows $C$. derbianus to usually go unnoticed (Steiner 1981; McClearn et al. 1994; Voss and Jansa 2009; Aranda-Sánchez 2012). Moreover, the arboreal habits of $C$. derbianus may lead them to frequently climb on power lines, as evidenced by records of electrocuted individuals (Saavedra-Rodríguez et al. 2013). However, when there is little canopy connectivity and an absence of artificial passages in human-dominated habitats, individuals may be forced to move on the ground, increasing their risk of being hit by a vehicle or being predated by domestic animals (Artavia et al. 2015; Hernández 2018).

Similar to other mesomammals, C. derbianus is prey of larger carnivores such as ocelots (Moreno et al. 2006) or birds of prey (Marineros et al. 2016). To our knowledge, we report the first two records of a spectacled owl ( $P$. perspicillata) as a predator of $C$. derbianus in Panamá, which has also been observed in Honduras (Marineros et al. 2016). In addition, we show that it is also preyed upon by domestic animals such as cats and dogs (Figure $2 \mathrm{H}$ ). Although C. derbianus might function as an important prey species in the trophic web of Neotropical forests, its ecological contributions as a seed disperser and a pollinating agent are likely more significant but remain poorly studied and mostly anectodical (Steiner 1981; Lessa and da Cota 2010; ArandaSánchez 2012; Kays et al. 2012). Our diet data suggest $C$. derbianus is mostly frugivorous, but it might also feed on small vertebrates or insects, flowers and nectar (Bucher and Hoffmann 1980; Kays et al. 2012). Finally, during our survey, we did not find any evidence of $C$. derbianus value for food, commercial, cultural, religious or domestic use. Nonetheless, it may be threatened by loss of habitat, persecuted for being considered detrimental to poultry farming or simply due to a lack of knowledge about the species. Our data compilation sheds more light on the distribution, ecology and conservation threats on C. derbianus in Panamá and could serve as a baseline for future studies.

\section{Acknowledgements}

We especially thank A. Rivera, B. Rodríguez, C. Castillo, C. Gernez, D. Aisprúa, E. Sanchez, E. Bonilla, H. Araúz, I. Cisneros, J. Medina, J. Pérez, M. González, P. Castillo, R. Morales, 


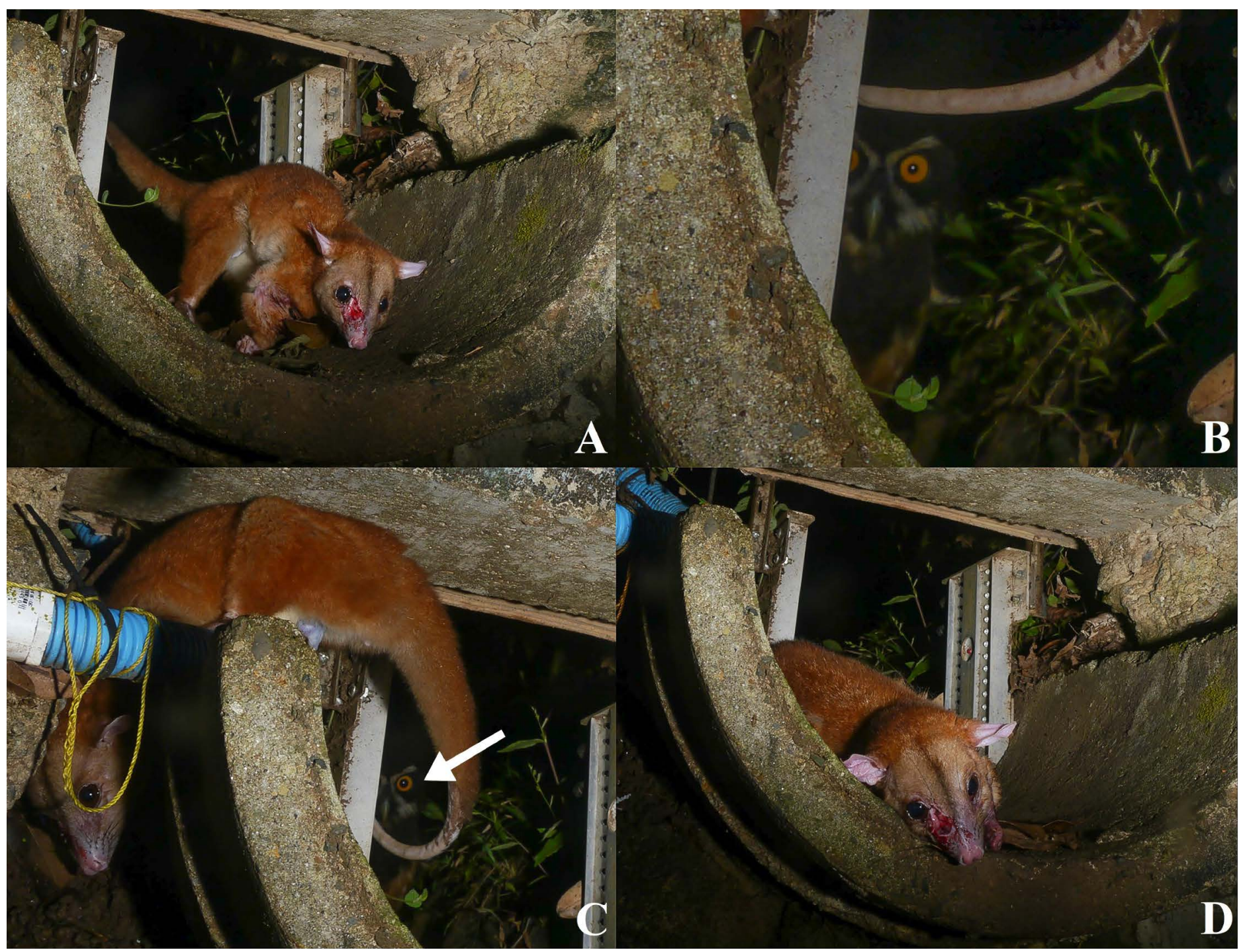

Figure 3. Photographic sequence, from A to D, of a deadly attack by a spectacled owl (Pulsatrix perspicillata) arrowed at C on a Central American woolly opossum in the island of Barro Colorado, province of Colon, Panamá. Photograph by I. Geipel.

V. De Gracias and V. Wilson, for providing us with multiple data and observations, as well as other anonymous people who provided data. M. Spicer and N. Meyer for the recommendations and review of the English grammar, as well as G. Berguido and Asociación ADOPTA Bosque Panamá for financing this work.

\section{Literature cited}

Amador, L. I., AND N. P. Giannini. 2016. Phylogeny and evolution of body mass in of Didelphis marsupialis (Marsupialia: Didelphimorphia: Didelphidae). Organisms Diversity \& Evolution 16:641-657.

Aranda-Sánchez, J. M. 2012. Manual para el rastreo de mamíferos silvestres en México. Comisión Nacional para el Conocimiento y Uso de la Biodiversidad. México City, México.

Artavia, A., M. Jiménez, A. Martínez-Salinas, E. Pomareda, D. Araya-Gamboa, and E. Aévalo-Huezo. 2015. Registro de mamíferos silvestres en la sección de la ampliación de la Ruta 32, Limón, Costa Rica. Brenesia 83-84:37-46.

Bucher, J. E., and R. S. Hoffmann. 1980. Caluromys derbianus. Mammalian Species 140:1-4.
Fonseca, R., ANd D. Astúa. 2015. Geographic variation in Caluromys derbianus and Caluromys lanatus (Didelphimorphia: Didelphidae). Zoologia 32:109-122.

HandLeY, JR. C. O. 1966. Checklist of the mammals of Panamá. Pp. 753-795 in Ectoparasites of Panamá (Wenzel, W. R., and Tipton, V. J., eds.). Field Museum of Natural History. Chicago, Illinois, U.S. A.

HernándeZ, L. 2018. Evaluating temporal and spatial trends in roadkill frequency in Central Panamá: A baseline study. Master dissertation. University of Bristol. United Kingdom.

Juste, J., ANd A. Guillén-Servent. 1997. Los mamíferos terrestres del Parque Nacional de Coiba (Panamá). Pp. 472.472 in Flora y Fauna del Parque Nacional Coiba, Inventario Preliminar (Castroviejo, S., eds.). Jardín Botánico. Madrid, España.

Kays, R., M. E. Rodríguez, L. M. Valencia, R. Horan, A. R. Smith, AND C. ZIEGLER. 2012. Animal visitation and pollination of flowering balsa trees (Ochroma pyramidale) in Panamá. Mesoamericana 16:56-70.

LEsSA, L.G., AND F. N. DA Costa. 2010. Diet and seed dispersal by five marsupials (Didelphimorphia: Didelphidae) in a Brazilian Cerrado Reserve. Mammalian Biology 75:10-16. 
Marineros, L. E., H. L. Vega, J. Adams, and M. McKewy. 2016. Notas y nuevos sitios de encuentro Caluromys derbianus (Marsupialia: Didelphidae) in Honduras. Biodiversidad Neotropical 6:77-84.

McClearn, D., J. Kohler, K. J. McGowan, E. Cedeno, L. G. CarBONE, AND D. Miller. 1994. Arboreal and terrestrial mammal trapping on Gigante Peninsula, Barro Colorado Nature Monument, Panamá. Biotropica 26:208-213.

Moreno, R., R. Kays, and R. JR. Samudio. 2006. Competitive release in diets of ocelots (Leopardus pardalis) and puma (Puma concolor) after jaguar (Panthera onca) decline. Journal of Mammalogy 87:808-16.

Reid, F. A. 2009. A field guide to the mammals of Central America and Southeast Mexico. Oxford University Press. New York, U. S. A.

SaAvedra-Rodríguez, C. A., A. Lizcano, and J. D. Corrales. 2013. Incidentes de fauna silvestre en líneas de energía en zona rural del Valle del Cauca, Colombia. Biodiversidad Neotropical 3:85-89.

Steiner, K. E. 1981. Nectarivory and potential pollination by a neotropical marsupial. Annals of the Missouri Botanical Garden 68:505-513.

Voss, R. S., AND Jansa, S. A. 2009. Phylogenetic relationships and classification of Didelphis marsupialis, an extant radiation of New World metatherian mammals. Bulletin of the American Museum of Natural History 322:1-177.

WAterhouse, G. R. 1841. The naturalist's library conducted by Sir William Jardine. Mammalia vol. XI. Marsupialia orpouched animals. W. H. Lizars. Edinburgh, United Kingdom.

Associated editor: Cristian Kraker-Castañeda

Submitted: August 21, 2020; Reviewed: January 14, 2021.

Accepted: January 22, 2021; Published on line: February 5, 2021. 